\title{
David Melendez
}

\section{Missionaries and Borderlands The Mission Play and Missionary Practices in Alta California} THERE was recently presented near Los Angeles, in its own theater, the first satisfactory combination of pageant and drama ever seen in this country.

The glamour and the romance of old Spain, which was the mother of California and the mother of America, is portrayed in the Mission Play by Franciscan monks, Spanish soldiers and sailors, Indians, picturesque adventurers, singers and dancers who are not only to the manner born, natives of the soil with the blood of Castile in their veins, but who are also actors trained to the highest degree of perfection. Moreover, the Play is equipped with scenery and properties of historical accuracy and is performed in a theatre specially constructed for the purpose. The most eminent critics have declared the Mission Play to be the greatest pageant-drama of this or any other country.

1 Willard Wright, "California's Mission Play," Harper's Weekly, July 6, 1912, 19.

${ }^{2}$ Vernon Selfridge, The Miracle Missions (Los Angeles: Grafton Publishing Corporation, 1915), n.p. 


\section{Introduction}

Described as a stunning combination of pageant and drama, The Mission Play, written by poet and historian John Steven McGroarty in 1911, was remarkable for the ways that it brought California history to life onstage. First presented in 1912 on the grounds of Mission San Gabriel near the city of Los Angeles, the play was one of the most significant theatrical attractions to Southern California in the early twentieth century. As it became an annual tradition, it coalesced into a Southern California institution, resulting in the building of the Mission Playhouse and formation of the Mission Play Corporation in 1927. More important, it is an excellent example of how theater participates in the writing of history. Through an interactive performance experience, the play cemented a narrative of salvation and progress, hailing the missionaries as having ushered civilization into the region when they arrived in the latter half of the eighteenth century.

However, the historical narrative which The Mission Play helped to popularize has been critiqued and challenged over the years. Among the points of critique are ways that it oversimplifies the complexity with which the missions of California came to house the difficult past of multiple colonial encounters. First, its focus on the missionaries as "great men" has defined California's colonial past in relation to the character of missionaries, enabling the mission past to stand in for Spanish and Mexican colonial rule over indigenous nations, before the us conquest of Mexican Alta California. And second, even though dynamics between California Indians and the Spanish, Mexican, and American colonizers produced distinct material conditions, historical narratives have generally locked the period into a dualism around the colonial legacy: did colonization constitute genocide of California Indians, or was the devastation of California Indian communities an unfortunate yet inevitable series of consequences of discovery and progress? This prevailing dualism has rendered the missions both as monuments to colonization and reminders of "Indigenous authority, memory, identity, and historical narration."3

The emerging field of Critical Mission Studies, an initiative between University of California faculty and California Indian research partners, demonstrates how the complexity of the mission past has come to the fore in recent rethinking of knowledge production at large us public universities. ${ }^{4}$ Indeed, the inclusion of California Indian leaders in the formulation of research agendas into the mission past is a major shift in that historic relationship, which was framed by mainstream narratives that the annexation of California was preordained through Manifest

3 Lisbeth Haas, Saints and Citizens: Indigenous Histories of Colonial Missions and Mexican California (Berkeley: University of California Press, 2014). 7.

4 "Who We Are," Critical Mission Studies website, accessed June 17, 2021, https://criticalmissionstudies.ucsd.edu/whowe-are/. 
Destiny. ${ }^{5}$ At the same time, beyond the university, missions and mission archives have recently curated speaker series and other initiatives that encourage collaboration between established researchers in the academy, Franciscan missionaries, and scholars of California Mission Indian descent, to bring forth a wide-ranging spectrum of perspectives on how to deal with the missions and their multilayered pasts organized in such a way as to give prominence to some events and, at the same time, to occlude certain historical subjects.

In this essay, I take up a core question of this issue of Pamiętnik Teatralny: how are we to think about historiography beyond a dualism, settled in time and reflective of the status quo? The Critical Mission Studies' imperative to "rewrite the history of California's missions" presents an opportunity to address this question by drawing attention to practices that shaped everyday mission life, and to how these practices obliterated material reality of California Indians ${ }^{6}$ and infiltrated and permeated pageant plays and historical melodramas that attempted to stage that history. I will discuss how conflicting and differential understandings of time, space, and matter were smoothed over and became invisible by missionary practices. In this enterprise, I will follow Gloria Anzaldúa’s turn toward borderlands thinking-one among other possible ways to go about rewriting the history of the California missions, which does not remain inscribed within the duality of inverting the symmetry of what is represented without questioning this duality. And this brings me to the core of my argument: the process of rewriting the history, or offering an alternative history, indeed, threatens to shift the symmetry of the dualism that has reduced the past to a representation that upholds the political, ideological, or academic status quo. However, simply shifting that dualism cannot reveal the contradictions that it has created. For that, historiography of borderlands thinking is necessary.

\section{The Mission Play (1911) - The Missionary Character}

The Mission Play is the most iconic theatrical representation of California mission history. It was incredibly popular; the playwright himself estimated that during its initial run (1912-1934), over one million people attended performances. ${ }^{7}$ Audiences found the play to be an engaging experience with strong moral and

5 Manifest Destiny is an idea, popularized in the mid-nineteenth century, that regards the territorial expansion of the us across the North American continent as an inevitable consequence of progress.

6 In this essay, the term "California Indian" reflects claims of indigenous sovereignty and governmental autonomy through time. Elsewhere, the term "indio" reflects the social distinction between so-called gente de razon (rational people) and indios that dictated colonial interactions in California under Spanish and Mexican rule.

7 John McGroarty, California of the South: A History, vol. 5 (Chicago: S. J. Clarke Publishing, 1935), 339-340. Others have estimated even higher numbers of attendance. 
spiritual messages about the power of faith. Yet the play also found success in how it facilitated the "whitewashing" of Los Angeles' Mexican heritage following the us acquisition of California at the end of the Us-Mexico War (1846-1848). ${ }^{8}$ Crafted by John McGroarty in consultation with mission historians, its performance was regarded as "history come to life." It was both an educational and moral/spiritual affair that enabled newcomers to the formerly Mexican state of California to claim the region's history as their own. Further, it was deemed a valuable experience for Mexican schoolchildren, in that it showed them the merits of assimilating from their Mexican backwardness to become part of the great American project.

The play itself takes audiences through the history of the missions, providing an allegory of progress culminating in the promise of us Westward expansion. Its dramatic arc hinges on the legacy of Saint Junipero Serra-founding father of the first California missions - and opens in 1769, as missionaries and soldiers await the coming of a much-needed supply ship while they fail repeatedly to attract and baptize California Indians around what is now the city of San Diego. ${ }^{9}$ The act ends in triumph, as God answers Serra's fervent prayers, interceding to bring the supply ship and a family of indios to baptize.

During the opening run of the production in 1912, an intermission between acts I and II allowed audiences to stroll through a walking path designed to be a miniature model of El Camino Real-the coastal highway that connected all twenty one Franciscan missions in Alta California. While walking along the path, audiences took note of carefully crafted miniature models made to represent each of the missions. This stroll through time was an affecting part of what was an immersive experience with history. ${ }^{10}$

Going back to their seats, the audience proceeded through the rest of the play, marveling at the cast of over a hundred players, which featured "native Indians" to give the production an added air of authenticity. The second act takes place fifteen years after the first and is set in Mission San Carlos (just under $200 \mathrm{~km} / 124 \mathrm{mi}$ south of San Francisco), capturing the golden age of the missions, identified as the year 1784. Here, romance and intrigue develop, and the plot revolves around Serra's refusal to allow the lecherous Comandante to marry a young "half-Indian" woman. Having successfully protected her by marrying her to another neophyte, Serra falls to his knees in prayer just before the curtain falls at the act's close. Suggesting to the audience that his death is imminent, Serra's prayer is a farewell

8 William F. Deverell, Whitewashed Adobe: The Rise of Los Angeles and the Remaking of Its Mexican Past (Berkeley: University of California Press, 2004), 207-249. According to Deverell's research, when the many revivals of the play are factored in, the number of audience actually exceeds 2.5 million, Deverell, Whitewashed Adobe, 240.

9 Junipero Serra was canonized in 2015 amid significant controversy. For a California Indian perspective, see Deborah A. Miranda, "Serra the Saint: Why Not?," Indian Country Today, January 26, 2015 (updated September 13, 2018), https:// indiancountrytoday.com/archive/serra-the-saint-why-not.

10 Eugene Sugranes, The Old San Gabriel Mission: Historical Notes Taken from Old Manuscripts and Records Accurately Compiled After Diligent Research (San Gabriel, cA: n.p., 1921), 81. 
that heightens the emotional connection the audience has developed with him as a revered historical and religious figure.

The final act of the play is set in 1844, in the ruins of Mission San Juan Capistrano (about $80 \mathrm{~km} / 50 \mathrm{mi}$ south of Los Angeles), long after Serra's death and the secularization of the missions." In the ruins, the audience is led to consider Serra's legacy to ask if and how the missions will endure through time, especially with the coming of the Americans. The indio Ubaldo has become the caretaker of the mission and reveals that he was the child, "the first of my race," whom Serra baptized earlier in act I. ${ }^{12}$ In the play's final moments, he speaks with Californio elite Señora Josefa Yorba about the coming of the Americans. While they speak, a group of indios return to the mission to bury a missionary who had starved to death while living with them in the countryside. The Señora is surprised by the indios' reverence for the missionary, and by the golden chalice that they had saved from the mission to bury with him. Seeing how Ubaldo and the indio pallbearers have kept faith in the mission, the Señora is able to see beyond the ruins and into a possible future. In a speech, she bids farewell to the bricks of adobe, suggesting that the mission has become part of the land itself. Just as the old Spanish race gave rise to the new race of faithful mission indios, she seems hopeful that the Americans will restore the missions to their former glory. The Señora observes:

The old race passes and the new race comes. This lovely land and all these golden shores that once were ours shall know the stranger's footstep now and echo to the stranger's voice. ${ }^{13}$

The Mission Play is one of many early twentieth-century theatrical events that dramatized an understanding of California history that conflated the coming of the Americans with progress. ${ }^{14}$ While other forms of cultural production were key to forming the image of a romantic and idyllic Spanish past, the medium of theater enabled audiences to experience that history as a cathartic set of unfolding events. ${ }^{15}$ Others have offered generative critiques about how The Mission Play

${ }^{11}$ The process of secularization took place in $1834-1835$, shifting control of the missions from the Franciscan religious order directly to the state.

12 John McGroarty, The Mission Play: A Pageant Play in Three Acts, 1911, pp. 3-4, Ayer Ms 546, The Newberry Library, Chicago, http://www.aihc.amdigital.co.uk.ezp2.lib.umn.edu/Documents/Details/Ayer_ms_546.

13 McGroarty, Mission Play, 17.

${ }^{14}$ Chelsea K. Vaughn, "The Joining of Historical Pageantry and the Spanish Fantasy Past: The Meeting of Señora Josefa Yorba and Lucretia del Valle," Journal of San Diego History 57, no. 4 (2011):213-235, https://sandiegohistory.org/journal/ v57-4/v57-4vaughn2.pdf.

15 Theatrical events included "Old Spanish Days" festivals, as well as parades, pageants, and stage plays. The most notable non-theatrical cultural production was Helen Hunt Jackson's novel, Ramona (1884). 
established and upheld the Spanish fantasy past. ${ }^{16}$ While useful, these critiques double-down on a dualism that hinders an analysis of how the figure of the missionary has been instrumentalized to uphold this fantasy.

In each of The Mission Play's three acts, the dramatic action revolves around the moral character of a missionary: Serra's grit, determination, and faith to found the mission in San Diego; Serra's bold, principled stand against the Comandante; and the committed leadership of the revered dead padre that indios take back to the mission to bury. In each act, it is the missionary who compels others to action and drives the pageant's drama. As the movers of history, the missionaries' practices are obscured by their dramatic character traits and dispositions. In this way, The Mission Play does not present missionaries as historical subjects, but as narrative objects of how Americans wanted to see themselves mapped onto the past.

By hinging the progression from past to present solely upon the character of missionaries, the play smooths over historical surfaces that were carved by conflicting understandings of time, space, and matter within the mission past. Drawing attention to tensions and contradictions within this historical constellation makes the play an exemplary site to contemplate a historiographic practice that reaches beyond a dualistic comparison. Contrary to the chronological narrative of The Mission Play, the mission past is not simply in temporal relationship with the present, but the present is also in a spatial arrangement with the past. To substantiate this last point, in the following section, I will discuss everyday missionary practices that The Mission Play obscured.

\section{Keeping Time, Producing Mission Space}

The Mission Play took inspiration from McGroarty's earlier historical work, California: Its History and Romance (1911). In his chapter "The Story of the Missions," McGroarty contextualizes the tremendous evangelizing efforts of missionaries by emphasizing what he regarded as the deplorable state of the indios' savage existence. According to him, they

were little above the level of the most degraded physical beings and the most mentally slothful human creatures on the face of the earth. A more hopeless task was never attempted by the agencies of religion and civilization .... ${ }^{17}$

\footnotetext{
16 Carey McWilliams, North from Mexico: The Spanish-Speaking People of the United States (Philadelphia: J. B. Lippincott, 1949), 35-47.

17 John McGroarty, California: Its History and Romance (Los Angeles: Grafton Publishing, 1911), 55.
} 
Thus, to McGroarty, the missionaries were heroes whose regime of discipline was a necessary part of transforming indios into self-sufficient people. He holds the establishment of the missions in such high esteem that he counts the founding of the California mission system among the five "miracles of achievement" that "stand out as climaxes in the pageant" of California's transformation into a global industrial and commercial center. ${ }^{18}$

Prior to the arrival of the Spanish in 1769, the region that would become Alta California was among the most linguistically diverse in the empire and densely populated by California Indians with vastly different systems of knowledge and lifeways. Spain's first attempt to colonize the region, the so-called Sacred Expedition, hinged on the founding of missions. The purpose of the missions was essentially two-fold: to convert indios to Christianity and to develop them into a productive, loyal workforce. This approach was aimed at quickly and efficiently gaining control over a critical mass of California Indians to secure the northern border of New Spain from the encroachment of competing world powers (Russians, English, Americans).

Over time, the twenty one Franciscan missions (1769-1835) grew to span the California coast and, as colonial institutions, they divided California Indians into two groups: the neophytes who affiliated with the missions, and the pagan indios who remained beyond mission control. As part of Spanish policy, the mission estates were in theory owned by the affiliated neophytes. The missionaries were only supposed to operate the missions for long enough to convert, "civilize," and prepare enough indios so that they could turn control of the mission church over to parish priests, and pass control of the mission lands to the neophytes, to whom those lands belonged. ${ }^{19}$ This turnover was a pivotal part of the plan, because it would then allow the missionaries to focus their efforts on establishing more missions further inland to bring more indios into colonial control. However, crucial aspects of this turnover never happened. Although the missions came under the control of the state and parish priests per decree of the Mexican government starting in 1833, the neophytes did not acquire the mission lands that were theirs by legal right.

Before the mission system in Alta California was secularized with the passage of the Mexican secularization act in 1833, the missions were key commercial centers in the region, because they controlled access to neophyte labor. Owing to Alta California's isolation from the rest of the Spanish empire (1769-1821) and independent Mexican nation, colonial agents in California depended on this labor to survive, since communication and the transfer of goods to/from the colonial center (Mexico City) was so difficult. California's isolation, geopolitical status as

\footnotetext{
18 McGroarty, California, 275

19 The missionaries were expected to make each mission ready for secularization within ten years of its founding.
} 
an international border, and its dependence on indigenous labor made its mission system markedly different from those in other parts of New Spain.

In general, colonial land-use practices, like damming rivers and clearing land for livestock grazing, effected significant social and environmental changes that impacted California Indians broadly. The formation of missions, presidios (forts), and agricultural sites stressed and/or disrupted traditional kinship networks, lifeways, and systems of knowledge foundational to California Indian communities. For neophytes, their interaction with colonial authorities also forged a new understanding of time and space in the mission that was neither indigenous nor strictly colonial.

Inadvertently, attention to practices employed by the missionaries to order and regulate time reveal contradictions between the identity imposed onto the past-the so-called "mission period" (1769-1835) — and the dynamics of space formed through social relations between colonial agents and California Indians. Consider the following practice: before commencing with the construction of any buildings, the missions were established through acts of public spectacle. According to the story of the founding of Mission San Antonio de Padua in 1771, mission president, Serra, ordered a bell to be hung in an oak tree and sounded to call indios to the founding of the mission. The dramatic account was documented by mission historian and Franciscan missionary Zephyrin Engelhardt in his foundational multi-volume The Missions and Missionaries of California:

When the mules had been relieved of their burdens, and the bell swung from a stout oak tree, the Fr. Presidente in a transport of zeal suddenly rang the bell and exclaimed in a loud voice: "Oh ye gentiles! Come, come to the holy Church! Come, come to receive the faith of Jesus Christ!" Amazed at this strange action of their superior Fr. Miguel said to him, "Why, Father, do you tire yourself? This is not the spot on which the church is to be built; nor is there a gentile in the whole vicinity. It is useless to ring the bell!" "Father," the Fr. Presidente pleaded, "let me give vent to my heart which desires that this bell might be heard all over the world, or at least by the heathens that live in this Sierra!"2o

More than even Serra, and his larger-than-life historical persona, the mission bell is the iconic symbol of the California missions, and its importance goes beyond defining the rustic mission aesthetic.

The ringing of the bell through the countryside was designed to summon California Indians not only to mark the occasion, but to instill in indios a colonial understanding of time, as evidenced in a series of responses by missionaries

20 Zephyrin Engelhardt, The Missions and Missionaries of California, vol. 2 (San Francisco: James H. Barry Company, 1912), 88. 
throughout Alta California to questions posed by the Spanish government in 1815 . The missionaries from Mission San Buenaventura wrote that:

[Pagan Indians'] dulness [sic] and ignorance knew nothing of calendars; and although their language has proper names for morning, noon, evening, and night, the pagans were wont to live according to their fancy, and did not understand what it had to do with their meals, activities, or rest. The neophytes, on the other hand, govern themselves in all this by the bell of the Mission. ${ }^{21}$

Because neophytes were being trained to labor and produce as subjects of the Spanish crown, they were habituated toward the missionaries' ideals of individual and collective "self-governance." More than just directing them to "meals, activities, or rest," timekeeping ordered social relations within the mission community and generated a habitus specific to that mission.

In their responses to those same questions, missionaries at Mission San Miguel indicate the degree to which timekeeping shaped social relations at the mission, and how they revolved around communal acts of fellowship and service to the mission community.

A half hour after sunrise they gather in the church to hear Mass during which they recite the catechism in their own language having taken their breakfast in the form of atole before. From church they go to their houses to fetch the tools they need to perform their labors until 10:30 A.M. After this they take dinner which consists of wheat, Indian corn, peas or cooked beans. Then they rest until 2 oclock (in summer until 3). Then they continue working until an hour before sunset after which they take atole, return to the church to recite the catechism and sing the Alabado or the Salve or Adorate, Santa Cruz. When the church services are over they return to their homes. This is their daily routine. ${ }^{22}$

As a practice, ringing the bell was not only a means of keeping time throughout the day, as described above, but also connected the daily routine with other distinct yet overlapping temporalities - the liturgical calendar and the pursuit of eternal salvation, for example. The missionaries juxtaposed this understanding of time against their perceptions of indigenous modes of keeping time, as missionaries at Mission San Carlos described:

${ }^{21}$ Zephyrin Engelhardt, "Interrogatorio Y Respuestas of Fr. José Señan," The Catholic Historical Review 5, no. 1 (1919): 61.

22 Response given by missionaries at Mission San Miguel, collected in Maynard J. Geiger and Clement W. Meighan, eds., As the Padres Saw Them: California Indian Life and Customs as Reported by the Franciscan Missionaries, 1813-1815 (Santa Barbara, CA: Santa Barbara Mission Archive Library, 1976), 82-83. 
They neither know their ages nor how many years have elapsed since the death of their grandfathers, fathers or mothers. These and similar questions were extremely displeasing to them and are so even at present. They remembered some epochs as when war was waged, when the sea was very angry (this according to their explanation and from signs which have been discovered must have been a terrible earthquake), when a ship arrived, etc. ${ }^{23}$

In their assessment of indio relationships to events of the past, the missionaries inadvertently reveal dissonance between colonial and indio practices of memory. Hence, indios attending mass to celebrate the death and resurrection of Christ would not only have confronted a foreign set of spiritual beliefs, but also a foreign relationship to the past and practices of memory. As a key instrument used to discipline California Indians, the bell called neophytes together to pray, learn, work, celebrate, and served as an alarm in times of danger. The bell was the sound that activated the mission as a community.

Because the missionaries established new understandings of time in the way that they formed the mission community, practices such as keeping time transformed the mission into a threshold space. More than symbolic, it was the bell's materiality as an object that enabled the sonic field of its ring to keep indigenous and colonial realities in tension. In the eighteenth and early nineteenth centuries in Alta California, iron was a foreign material that had only slowly been implemented into everyday practice in the form of nails, horseshoes, and small tools. The supply of iron ore that the few blacksmiths in Alta California relied upon were entirely imported and always scarce, as there was no mining infrastructure or industry in the region at that time. The bells themselves were often gifts from other colonies in New Spain, and therefore signaled to neophytes the worlds beyond the ocean to which they now belonged. As a technology, the bell thus signaled the dissonance between the world that the missionaries had brought with them and the communities that the neophytes had left behind to affiliate with the mission.

Through conversion, baptized indios were also required to accept spiritual beliefs and internalize the missionaries' scientific reasoning. Although the mission reality was separate from the indigenous realities that the neophytes were expected to unlearn, these worlds existed simultaneously in the same physical space of the mission. Considering that mission space was formed according to the site- and time-specific conditions, which were shaped by practices in the missions, historians have obscured the presence of discordant temporalities and spatiality by adhering to a singular understanding of time and space defining the missions as institutions created by missionaries as institutional actors. This

23 Geiger and Meighan, As the Padres Saw Them, 83. 
has made it possible for historians to conflate the missions, as institutions, with mission space.

The problem with this conflation is that the missionary, as a historical figure, has become a composite of all missionary activities that were undertaken in the missions. This creates the perception that it was missionaries who created the missions, and not the complex web of practices-of which California Indians were the most crucial actors-that molded mission space. The consequence of this is that the history of the missions has glossed over practices in favor of actors, and therefore has privileged narratives of cultural conflict over analyses of how time and space were produced in the mission. For example, as evidenced by Engelhardt's already referenced mission histories upon which modern mission historiography is based, there is a prevailing sense that missionary activities established and drove history amid a conflict between indigenous and colonial cultures. This dualism has largely set the terms for how to think about the mission past. The debates that this engenders around decolonization, for example, are always reflective of the status quo, which cannot but comprehend the colonial legacy as a form of cultural supremacy. To unsettle this dualism, which is necessary to understand the impacts of the colonial legacy, a historiographic approach must confront how mission histories have conflated "culture" with practices that produced mission space. When considering how to rewrite the history of the missions, then, the fundamental issue is historiographic: If missionaries held the power to determine the rules of both time and space in the missions, their practices were not the exercise of cultural supremacy, which is today contested, but the act of producing mission time and space, which eliminated the inadequation between what indios were and what the monastic status quo wanted them to be.

It also means that the dualism that has dominated historical discourse about the California missions is not an effective way to contemplate the past. This is especially important, given that so much of what makes the mission past difficult is the longstanding practice of projecting universal understandings of time and space onto the past. To take hold of this uncertainty, a turn toward borderlands thinking is one among other possible ways to think more generatively about how to go about rewriting the history of the California missions.

\section{Mission Space Is the Borderlands}

Through practices of keeping time, the mission became a threshold where all that had been prior to missionization grated against all that was yet to pass. To move beyond a temporal relationship and a causal understanding of events is to experience a constellation of events that make multiple pasts, multiple chronologies, and multiple temporal organization visible, no matter how contradictory they 
may be. What mission history has yet to elaborate upon is precisely this fundamental set of contradictions that its own writing has seemed to have resolved. Yet it is everywhere apparent that this resolution is illusory. The mission past, in its complexity, constantly fights against the history that has upheld a reality foreign to it. If, indeed, mission space was produced through constant conflicts between different material realities, it is closer to the idea of the borderlands rather than a homogeneous mission place. More than just a boundary between one reality and another-the way that the Us-Mexico border, for example, divides one country from the other-the borderlands is a space where both of those realities exist simultaneously, forcing users to develop practices to navigate through them to produce an entirely distinct subjectivity. Not one, not the other, but both and neither.

In her poem, "In the Borderlands...," Gloria Anzaldúa situates the borderlands, as a space, directly onto the users of that space-they are not simply users of the space, but rather, they are the space itself. As a contradictory space, ${ }^{24}$ the borderlands, and therefore the users of the space, cannot manufacture consensus around what they are. They can only exist dialectically, identified within a dualism that is always already insufficient. In the borderlands, identity is both crucial and useless:
In the Borderlands
you are the battleground
where enemies are kin to each other
you are at home, a stranger,
the border disputes have been settled
the volley of shots have shattered the truce
you are wounded, lost in action
dead, fighting back. ${ }^{25}$

In the borderlands, one can be wounded, lost, dead, and fighting back all at once in a conflict declared to be ended, yet where combatants fight from even beyond death. This, I suggest, is not a matter of identity, but of how conflicting realities make identity both covetous and absurd. It is a space where one will die to have a name, only to fight against being named.

A foundational text within the field of Chicana/o studies, Gloria Anzaldúa's Borderlands/La Frontera formulates a theory of an indeterminate space that creates the conditions necessary for the emergence of a "new mestiza consciousness." ${ }^{26}$ She places her own subjective experience, as a Chicana lesbian, alongside the active site

\footnotetext{
24 Henri Lefebvre, The Production of Space, trans. Donald Nicholson-Smith (Oxford: Blackwell, 1991), 306.

25 Gloria Anzaldúa, "To Live in the Borderlands Means You," in Borderlands/La Frontera: The New Mestiza (San Francisco: Aunt Lute Books, 1987), 195.

${ }^{26}$ Gloria Anzaldúa, "La conciencia de la mestiza: Towards a New Consciousness," in Borderlands/La Frontera, 77-98.
} 
of material and ideological conflict of the South Texas us border with Mexico. The borderlands are not a metaphor to describe partitions (material or ideological), but a means of confronting indeterminacy and acknowledging how the process of partitioning creates a dialectical relationship of identity, with the self as other. In the borderlands, one is simultaneously at home and a stranger. It is a space where there can be no resolution, only movement toward new forms of consciousness.

This sense of ethics, of "not being at home in one's home," echoes Theodor Adorno's "Refuge for the homeless" in which he considers the paradox of being driven to ownership to overcome the relations of ownership, only to be plunged deeper into those relations. ${ }^{27}$ Formed by the conflict of opposing material realities, there is no exit from the borderlands, only movement through them. As a consequence, the borderlands have no concrete identity, but can only ever be identified by what they are not-ni de aquí, ni de alá (neither from here nor there). The borderlands are fundamentally a site of nonidentity, encompassing what Adorno has elsewhere conceptualized as the "dialectics of identity." ${ }^{28}$ To Adorno, nonidentity is a means of thinking about how identity, as a universal concept, is fulfilled by the particular. Attention to the inadequation of identity-how it conflates the universal and particular-makes it possible to understand multiple dualities acting on and subverting identity:

Reciprocal criticism of the universal, and of the particular; identifying acts of judgement whether the concept does justice to what it covers, and whether the particular fulfills its concept-these constitute the medium of thinking about the nonidentity of particular and concept. ${ }^{29}$

While Anzaldúa theorized the particular conditions of South Texas, her insights have been considered throughout the world. Her work has even been taken up in the context of the borderlands of Poland. ${ }^{30}$ In one section of her work, she discusses the possibility of a "new mestiza consciousness" that is activated by the act of crossing:

But it is not enough to stand on the opposite river bank, shouting questions, challenging patriarchal white conventions. A counterstance locks one into a duel of oppressor and oppressed; locked in mortal combat ... But it is not a way of life. At some point, on our way to a new consciousness, we will have to leave the opposite

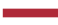

27 Theodor Adorno, Minima Moralia: Reflections from Damaged Life, trans. E. F. N. Jephcott (London: Verso, 2005), 38-39.

28 Theodor Adorno, Negative Dialectics, trans. E. B. Ashton (New York: Seabury Press, 1973), 146-148.

29 Adorno, Negative Dialectics, 146 .

30 See, for example, Ewa Majewska, "La Mestiza from Ukraine? Border Crossing with Gloria Anzaldúa," Signs: Journal of Women in Culture and Society 37, no. 1 (2011):34-41, https://doi.org/10.1086/660173; Grażyna Zygadło, "'Where the Third World Grates against the First': Teaching Gloria Anzaldúa from a Polish Perspective," Signs: Journal of Women in Culture and Society 37, no. 1 (2011):29-34, https://doi.org/10.1086/66o288.
} 
bank, the split between the two mortal combatants somehow healed so that we are on both shores at once and, at once, see through serpent and eagle eyes.... The possibilities are numerous once we decide to act and not react. ${ }^{31}$

The river, according to Anzaldúa, divides the oppressor from the oppressed and locks them in "mortal combat." This struggle is not merely political, in the sense that the combatants are either "right" or "wrong." To Anzaldúa, the struggle is a path to a new consciousness, and her call to action is to move beyond the identity that ties the self to one shore or the other and embrace the oppressor-oppressed confrontation dialectically. Anzaldúa would have us see that we are already on each shore, and urge us to leave each shore for the other, but not because the crossing will place one on the side of justice. To pursue a "new consciousness," one must leave each shore simultaneously, so that one has crossed to inhabit both shores anew, and through the crossing, emerge on each side "somehow healed." This movement cannot end the mortal combat, but it does multiply the subjectivities of the one who crosses, so that on each side of the river, one sees "through eagle and serpent eyes."

Anzaldúa's river encapsulates the borderlands as the threshold where the "now" is joined to the "what has been." Like Heraclitus' river, the water of which can never be the same twice, Anzaldúa's river is a site of flux that not only changes as it passes by each shore, but by its existence alone creates the conditions that make each crossing a movement toward a "new" consciousness. As a historiographic mode, crossing through the borderlands reveals different constellations of objects that were formed to impose an identity onto them. The crossing happens simultaneously, as a heterological encounter with the self as other, which does not resolve, but rather multiplies subjectivity.

The moment of Anzaldúa's crossing, where the "now" encounters the "what has been," encompasses Walter Benjamin's constellation. He confirms that the arrangement one sees depends entirely on how one is positioned in relation to "history," so that what is revealed through a dialectical encounter is a result of that particular configuration. Coming together "in a flash," Benjamin's constellation cannot be formed or created, because it is an "image" that emerges when dialectics are slowed to "a standstill." ${ }^{2}$ Whereas Anzaldúa's focus is on the movement of crossing and the process of forming a new consciousness, Benjamin homes in on what becomes visible when movement is suspended within the dialectical encounter with the self as other. The possibilities of this encounter are without end, because, as Benjamin states, the dialectical relationships that form the image

\footnotetext{
${ }^{31}$ Anzaldúa, "Towards a New Consciousness," 78-79.

32 Walter Benjamin, "Convolute N: On the Theory of Knowledge, Theory of Progress," in The Arcades Project, trans. Howard Eiland and Kevin McLaughlin (Cambridge, MA: Harvard University Press, 1999), 463.
} 
are not defined by present and past (or future), but by "what has been" and the "now." This distinction is crucial, because it means that these relationships are dialectical and spatial, not merely temporal. The composite "what has been" is not a part of a defined teleology, but a collection of events that come into focus dialectically in relation to the moment of the now. ${ }^{33}$

Borderlands is a form of spatial dialectics that does not seek resolution, because there can be no resolution without also suspending the dialectics. The dualism that the writing of history has produced cannot be overcome. Although the dualism is not inherent to the space it describes, it exists. It is not imaginary, even though it was imagined into being. A mode of thinking like borderlands is important to the rewriting of history because its aims are to rearrange the image-dialectics at a standstill - with each crossing.

\section{Conclusion}

A focus on practices through the borderlands also has a bearing on the relationship between theater and history. In theatrical works that produce a fantasy of the past, like The Mission Play, it is not enough to point to the representation and call it a fantasy, because at some point, the fantasy has become real. What, then, is to be done with a pageant drama like The Mission Play, whose fantasy has been so powerful and enduring that it has, as William Deverell has described, "whitewashed" the adobe of the missions?

The Mission Play, as well as other similar historical pageant-dramas, has found it increasingly difficult to assemble audiences willing to tolerate its "misrepresentations" of the past and celebratory narrative of colonization. However, "more accurate" representations of the past run the risk of layering yet another set of narratives atop a dualism that has only benefitted he status quo. A historiographic approach to The Mission Play should attend to how the mission itself was a space produced by practices, and how, as a threshold, different material realities were in continuous conflict with one another. As borderlands, spatial dialectics-the endless collecting and rearranging of fragments - can embrace a relationship between the mission past and fantasies about it to give rise to different subjectivities. With these subjectivities, it becomes possible to move around the many contradictions of the past and sustain a complex relationship with it-to simultaneously inhabit multiple subjectivities and contradictory perspectives: to be at once on both shores, witnessing the past through the eyes of the eagle and the serpent.

33 Benjamin describes the time of the now, Jetztzeit, as distinct from the present, because it has been dislodged from historical time and has revolutionary potential. See Walter Benjamin, "Theses on the Philosophy of History: Thesis XIV", in Illuminations: Essays and Reflections, ed. Hannah Arendt, trans. Harry Zohn (New York: Schocken Books, 1969), 261. 


\section{Bibliography}

Adorno, Theodor. Negative Dialectics. Translated by E. B. Ashton. New York: Seabury Press, 1973.

Adorno, Theodor. Minima Moralia: Reflections on a Damaged Life. Translated by E. F. N. Jephcott. London: Verso, 2005.

Anzaldúa, Gloria. Borderlands/La Frontera: The New Mestiza. San Francisco: Aunt Lute Books, 1987.

Benjamin, Walter. Illuminations: Essays and Reflections. Edited by Hannah Arendt. Translated by Harry Zohn. New York: Schocken Books, 1969.

Benjamin, Walter. The Arcades Project. Translated by Howard Eiland and Kevin McLaughlin. Cambridge, MA: Harvard University Press, 1999.

Deverell, William F. Whitewashed Adobe: The Rise of Los Angeles and the Remaking of Its Mexican Past. Berkeley: University of California Press, 2004.

Engelhardt, Zephyrin. The Missions and Missionaries of California. 4 vols. San Francisco: James H. Barry Company, 1908-1915.

Engelhardt, Zephyrin. “Interrogatorio Y Respuestas of Fr. José Señan.” The Catholic Historical Review 5, no. 1 (1919): 55-66.

Geiger, Maynard J., and Clement W. Meighan, eds. As the Padres Saw Them: California Indian Life and Customs as Reported by the Franciscan Missionaries, 1813-1815. Santa Barbara, CA: Santa Barbara Mission Archive Library, 1976.

Haas, Lisbeth. Saints and Citizens: Indigenous Histories of Colonial Missions and Mexican California. Berkeley: University of California Press, 2014.

Lefebvre, Henri. The Production of Space. Translated by Donald Nicholson-Smith. Oxford: Blackwell, 1991.

McGroarty, John. California: Its History and Romance. Los Angeles: Grafton Publishing, 1911. McGroarty, John. California of the South: A History. Chicago: S. J. Clarke Publishing, 1935.

McWilliams, Carey. North from Mexico: The Spanish-Speaking People of the United States. Philadelphia: J. B. Lippincott, 1949.

Miranda, Deborah A. "Serra the Saint: Why Not?" Indian Country Today, January 26, 2015 (updated September 13, 2018). https://indiancountrytoday.com/archive/serrathe-saint-why-not.

Selfridge, Vernon. The Miracle Missions. Los Angeles: Grafton Publishing Corporation, 1915. Sugranes, Eugene. The Old San Gabriel Mission: Historical Notes Taken From Old Manuscripts and Records. San Gabriel, cA: n.p., 1921.

Vaughn, Chelsea K. "The Joining of Historical Pageantry and the Spanish Fantasy Past: The Meeting of Señora Josefa Yorba and Lucretia del Valle." Journal of San Diego History 57, no. 4 (2011): 213-235. https://sandiegohistory.org/journal/v57-4/v57-4vaughn2.pdf.

Wright, Willard. “California’s Mission Play." Harper's Weekly, July 6, 1912. 


\section{Abstract}

\section{Missionaries and Borderlands: The Mission Play and Missionary Practices in Alta California}

This essay takes up a core question of this issue of Pamiętnik Teatralny: how are we to think about historiography beyond a dualism, settled in time and reflective of the status quo? With respect to the California missions, historical treatments of colonization revolve around a dualism shaped by moral dimensions of the missionary enterprise-did the missions help California Indians or harm them? Theatrical representations, like the wildly successful early twentieth century pageant drama, The Mission Play, staged a version of mission history that argued for the former. As a representation of the mission past, the play conflated missions, as institutions, with the moral character of missionaries, thus edifying a fantasy and entrenching the dualism. However, attention to missionary practices, like keeping time using the mission bell, reveal how the missions were sites where indigenous and colonial realities were in constant conflict. Through practices, relations between missionaries and indios produced a space that was neither strictly colonial nor indigenous, and yet both - a borderland. As a mode of spatial dialectics, borderlands thinking can unsettle the duality underlying representations of the mission past to question how that dualism has come into being.

\section{Keywords}

theater historiography, California Indians, Alta California, Critical Mission Studies, pageant drama, Chicana/o history, borderlands

\section{Abstrakt}

\section{Misjonarze i pogranicza: The Mission Play i praktyki misyjne w Alta California}

Artykuł podejmuje kluczowe pytanie tego zeszytu „Pamiętnika Teatralnego”: jak mamy myśleć o historiografii, jeśli chcemy przekroczyć dualizm, wynikający z osadzania wydarzeń w czasie i odzwierciedlania status quo. W odniesieniu do misji kalifornijskich historyczne ujęcia kolonizacji oscylują wokół binarnego myślenia o moralnym wymiarze tych przedsięwzięć: czy misje pomogły kalifornijskim Indianom, czy też im zaszkodziły. Przedstawienia teatralne, na przykład cieszące się wielkim powodzeniem na początku xx wieku misterium The Mission Play, przedstawiały taką wersję historii misji, która dowodziła słuszności pierwszej interpretacji. Jako reprezentacja dziejów misyjnej działalności sztuka wiązała instytucję misji z moralnością misjonarzy, konstruując w ten sposób fantazję i utrwalając dualistyczną perspektywę. Jednak analiza praktyk misyjnych, takich jak odmierzanie czasu za pomocą dzwonu, ujawnia, że misje były miejscem ciągłego konfliktu między tubylczą a kolonialną rzeczywistością. W praktyce relacje między misjonarzami i autochtonami wytworzyły przestrzeń, która nie była ani ściśle kolonialna, ani rdzenna, choć miała po trosze z obu jako przestrzeń pograniczna. Refleksja nad pograniczem, jako kategorią dialektyki przestrzennej, może podważyć dualizm leżący u podstaw reprezentacji dziejów misji, a zarazem unaocznić, w jaki sposób ten dualizm powstał. 


\section{Słowa kluczowe}

historiografia teatru, kalifornijscy Indianie, Alta California, Critical Mission Studies, misterium, historia Chicana/o, pogranicze

\section{DAVID MELENDEZ}

$\mathrm{PhD}$ candidate in Theatre Historiography in the Department of Theatre Arts \& Dance; and a graduate instructor in the department of Chicano and Latino Studies at the University of Minnesota. 